\title{
LIBRARIES AND READING HABITS AMONG ELEMENTARY SCHOOL CHILDREN: THE CONCEPT OF THE CLASSROOM COLLECTION
}

\author{
Dr. Snunith Shoham \\ Department of Information Studies \& Librarianship \\ Bar-Ilan University, Ramat-Gan 52900, Israel
}

\begin{abstract}
The elementary school regards the development of reading skills and the cultivation of free reading among students as one of its tasks. one of its ways of achieving this is to operate libraries in the school. Some schools provide only a central library. Some societies or locales, however, also believe in operating classroom collections in the elementary grades, so as to increase children' a exposure to books and reading. The reading habits of 301 fourth-grade students in Israel were examined. The sample included: (a) children who participated in a class library project in grades 2-3, with a central library also existing in the school; (b) children who participated in a class-library project in grades 2-3, with no central library in the school; and (c) children who did not participate in a class-library project, while having a central library in the school. Certain contribution of the class library project emerges, but the realization of this contribution depends on the existence of a central library in the school. A class library is not a substitute for a central collection. It can only constitute one approach among different approaches that can encourage children reading.
\end{abstract}

\section{INTRODUCTION}

Children read to satisfy the natural urge of curiosity and to broaden their understanding of the world they live in. Reading satisfies additional needs of the child: coping with challenges, a sense of security, gaining approval, a sense of belonging, being loved, the quest $\mathrm{f}$ or identity, and identification with historical figures or fictional characters. Stephen Krashen (1993) summarizes studies that indicate the power of reading. Research results have shown that reading contributes to improvement of vocabulary, spelling, writing style, reading comprehension, and of grammatical development.

Daniel Boorstin (1984) maintains that free reading, or the lack of it, is what determines a society's extent of advancement and enlightenment, cultural characteristics, and capacity for intellectual self-rule; therefore, one of the goals of an enlightened society is that its members will be "readers for pleasure" or "free readers." The process of becoming a free reader is a gradual one. Chall (1983) posits six stages through which the child passes from beginning reader to skilled reader, and ultimately to free reader:

Stage 0: Prereading: the preparing stage - occurs during the preschool age - birth to age 6 .

Stage 1: Initial reading, or decoding stage - occurs during grade

1-2, ages 6-7. The essential aspect of Stage 1 is learning

the arbitrary set of letters and associating these with

the corresponding parts of the spoken words.

Stage 2. Confirmation, fluency, ungluing from the print - occurs during grades 2-3, ages 7-8. Reading in Stage 2

consolidates what was learned in Stage 1.

Stage 3. Reading for learning the new- new knowledge, information, thoughts, and experiences - occurs during grade 4-8.

Stage 4: The stage of having multiple viewpoints - occurs during high school, ages 14-18. 
Stage 5: Construction and reconstruction - occurs during college/ university, age 18 and above. In this stage the reader is able to use selectively the printed material in those areas of knowledge central to one's concern.

Chall argues that Stage 2, that of fluency, which occurs during grades 2-3, is the focus of interest as far as reading for pleasure is concerned. The transformation of a beginning reader into a free reader is dependent on this stage.

Anderson, Wilson and Fielding (1988) found that the measure of the amount of time devoted to reading in the period from grade 2 to grade 5 is the best predictor of the child' a development as a reader. Morrow(1983) maintains that reading habits take shape up to grade 6. At that age, the child' s "reading type', is already an irreversible fact. Hence, the development of reading skills and the cultivation of free reading among students form one of the main task, of the elementary school.

Schools employ motivational reading activities of various kinds:

a. Providing children with opportunities, time, and materials to engage in book-related activities by:

- Placing large selections of popular books in school, e.g., "book f lood" projects in New Zealand and Great Britain (Krashen, 1993)

- Present literature to children daily (Hickman, 1981)

- Free silent reading in class (Krashen, 1993)

- Reading aloud in class (Fitzbgibbons, 1994)

- Discussion of books with teachers or librarians (Nilsson, 1987).

b. Creative activities:

- Sharing books through written or oral communication, in visual form, or by videos, displays, etc.

- Having children make their own books (Morrow \& Weinstein, 1986) Using creative storytelling techniques, e.g., puppet shows, music stories (Morrow \& Weinstein, 1986)

c. Activities that encourage reading outside of school:

- Reading time outside the classroom, such as reading at home specified as an assignment, or reading with a parent (Fitzgibbons, 1994)

One of the ways to encourage reading is to operate libraries in the school. Librarians believe that this enriches the print environment and results in more reading. Gaver (1963) reported that children who had access to school libraries did more reading than those who did not have a library in their school.

Some schools provide only a central library that constitutes an inclusive resource center and serves all the grades in the school with their different needs. Some societies or locales, however, also believe in providing classroom collections in the elementary grades, so as to increase children, s exposure to books and reading.

In Israel, the Ministry of Education and culture has for a number of years conducted a classlibrary project for grades 2 and 3 (recently extended to grade 1).

The fact that this project is associated with, and encouraged by, the Ministry of Education and Culture is expressed both in the budgeting of the project and in the lists of recommended books. At present, the project encompasses hundreds of schools throughout the country. It is managed by regional coordinators who supervise and work with the participating schools.

\section{THE CLASSROOM LIBRARY}

The classroom library is usually situated in a special corner of the classroom containing an assortment of books in various fields of interest and at different levels of difficulty together with additional art materials and work kits (Stott, 1967; Hepler, 1992). Books are usually those designated for lower grades, and can be read in class or at home on a borrowing basis. The advantage of the class library is the enhanced exposure to books. Studies have shown that immediate exposure to books increases free reading by children (Bissett, 1969). Some maintain that the existence of a class library contributes to greater involvement and sense of belonging among students to the encouragement of reading, to development of awareness of the library, and to children's understanding that teachers regard reading as an important activity, as well as enabling teachers to relate personally to children and their reading (Bavakutty, 1981; Memory, 1981). 
The classroom library can contribute to encouraging reading only in conjunction with the proper physical conditions, which create an atmosphere of "invitation to reading" for children-- such as, for example, a rug, cushions, open and attractive shelves, displays of books and book jackets. Studies have found that children do not use class libraries that are slovenly or unsightly; whereas children in kindergartens where there were good class libraries, chose, in their free time, to participate in reading activities (Morrow \& Weinstein, 1986).

Fractor et al. (1993) indicate a number of necessary features for classroom libraries: attractive and highly visible area, separated from the rest of the classroom; special seating arrangement, in an area that can accommodate at least five to six pupils at a time; a variety of genres and reading levels, with at least five to six books per student; and literature-oriented displays.

Nevertheless, one of the weaknesses of the class library is the shortage of resources, which detracts from the goal for which such libraries are established. Many libraries contain very few books, some of which were acquired as gifts or from children's homes and are therefore inappropriate for encouragement of reading. Mary Francis (1989) points to the related disadvantage that these small amounts of books may include familiar volumes that children have seen over and over again.

Morrow (1987) describes a project that was implemented in four recreational day care centers in New York, combining library corners with a recreational reading program. As a result of the project, the children's attitudes toward books improved and increase use of books was reported in all four centers.

Morrow and Weinstein (1982) conducted observations in 13 kindergarten classrooms of literature use by children in their free time. In some of the kindergartens a classroom reading program was implemented; in others the library corners were redesigned; in still others both the program and the design were implemented and there was also a control group. Data were collected before and then one week after the introduction of the changes (for two weeks period).

Literature use was significantly greater in all three experimental conditions than in the control condition. However, the changes produced by the three experimental conditions did not differ significantly from one another.

In another study, Morrow and Weinstein (1986) investigated the effects of both literature activities and the creating of attractive library center on 142 second-grade children' $\mathrm{s}$ voluntary reading. One group of students received school-based intervention only; second group received school -based intervention plus a reading-at-home program; the third was a control group.

Both the implementation of regularly scheduled literature activities and the creation of appealing library centers led to a substantial increase in children' s selection of literature during freechoice time. However, no effect on voluntary reading at home was found (as reported both by the children and by their parents).

Gaver (1963) conducted a study among sixth-grade students of six schools; two of the schools had central collections administered by one of the teachers, two contained classroom collections, and the other two had a central school library, administered by librarians and serving both the students and the teachers.

Both the quantity and the quality of the materials read were higher in the school library category. Over a three-month period, students in schools with a central library read an average of 14 books (during a three months period), compared to 6-9 in the other schools. They also read more varied material: three genres on average compared to only two among the other schools' students.

However, a study that was conducted for the British School Council in 193 elementary schools and 188 secondary schools found less free reading among students from schools with classroom libraries (all these schools also had a central library) compared to students from schools with central libraries only (Great Britain. School Council, 1977).

\section{THE STUDY}

Despite the possible importance of class libraries, only a small number of studies have assessed their effects. Most of these studies focused on children's reading habits while they were participating in a class-library project, but not on the long-range effects of the projects. The present study's objective was to investigate the relations between the type of school library and the students I reading habits over the long range. 


\section{The study's hypothesis}

Students who have a central library in their school together with classroom collections read more than students whose school has only a central library or only classroom collections.

Reading was measured by:

1. Amount of reading

2. Average number of hours per day devoted to free reading

3. Having library-borrowed books at home

\section{Research design}

Questionnaires were distributed among a sample of 301 fourth-grade students from four elementary schools. The socio-demographic characteristics of the four schools' students were quite similar: center of the country, urban areas, middle-class. The sample included:

(a) children who participated in the class-library project in grades 2-3, with a central library also existing in the school (107 students)

(b) children who participated in the class-library project in grades 2-3, with no central library in the school, but with classroom collections in all the classes including the fourth grade (91 students)

(c) children who did not participate in a class-library project, while having a central library in the school (103 students)

Some $6.3 \%$ of the subjects (19) did not have books for free reading of their own, $24 \%$ (72) had only few reading books at home, and 69.7\%- (209) had many private books at home (see Table 1) (Reading books exclude reference and non fiction materials). Comparing the students by their school libraries reveals a picture that is largely similar, although few more books were owned by students in whose schools there were central libraries only and more books by students whose schools had central libraries and who had also undergone a class library project in grades 2-3, hereafter referred to as combined libraries.

Table 1

Amount Of Private Books By Type Of School Library

\begin{tabular}{|c|c|c|c|c|c|c|c|}
\hline $\begin{array}{l}\text { No. of Reading } \\
\text { Books at Home }\end{array}$ & \multicolumn{2}{|c|}{$\begin{array}{l}\text { Combined } \\
\text { Libraries }\end{array}$} & \multicolumn{2}{|c|}{$\begin{array}{l}\text { Central } \\
\text { Library }\end{array}$} & \multicolumn{2}{|c|}{$\begin{array}{l}\text { Classroom } \\
\text { Library }\end{array}$} & Total \\
\hline No books & 9 & $(8.5 \%-)$ & 5 & $(4.9 \%)$ & 5 & $(5.5 \%)$ & $196.3 \%$ \\
\hline Few & 18 & $(17 \%)$ & 26 & $(25.2 \%)$ & 28 & $(30.8 \%)$ & $72 \quad 24.0 \%$ \\
\hline \multirow[t]{2}{*}{ Many } & 79 & $(74.5 \%)$ & 72 & $(69.9 \%)$ & 58 & $(63.7 \%)$ & $20969.7 \%$ \\
\hline & 106 & & 103 & & $n=91$ & & $=300$ \\
\hline
\end{tabular}

\section{RESULTS}

In table 2 amount of book reading by the study subjects is details according to type of library in the school. The table shows that the percentages of students who could be called intensive readers (reading 1-2 books per week) are similar between students in schools with class libraries only (72.6\%) and students in schools with combined libraries (69.2\%). In schools with a central library only, only 60.8 of the students responded that they read at least one book per week. As for reading at least one book every two weeks, the percentages are $96.3 \%$ - of students in schools with combined libraries, 93.5\% - of students in schools with a class library only, and $83.3 \%$ of students in schools with a central library only. 
Table 2

Amount Of Books Read According To Type Of Library

$\begin{array}{cccc}\text { Classroom } & \text { Central } & \text { Combined } & \text { Total } \\ \text { Libraries } & \text { Library } & \text { Library } & \end{array}$

\begin{tabular}{|c|c|c|c|c|c|c|c|c|}
\hline $\begin{array}{l}2+\text { books } \\
\text { per week }\end{array}$ & 34 & $37.4 \%$ & 32 & $32.4 \%$ & 22 & $20.6 \%$ & 88 & $29.3 \%$ \\
\hline $\begin{array}{l}1 \text { book } \\
\text { per week }\end{array}$ & 32 & $35.2 \%$ & 30 & $29.4 \%$ & 52 & $48.6 \%$ & 114 & $38.0 \%$ \\
\hline $\begin{array}{l}1 \text { book } \\
\text { per } 2 \text { weeks }\end{array}$ & 19 & $20.9 \%$ & 23 & $22.5 \%$ & 29 & $27.1 \%$ & 71 & $23.7 \%$ \\
\hline $\begin{array}{l}1 \text { book } \\
\text { per } 2 \text { months }\end{array}$ & 4 & $4.4 \%$ & 12 & $11.8 \%$ & 4 & $3.7 \%$ & 20 & $6.7 \%$ \\
\hline $\begin{array}{l}1 \text { book } \\
\text { per } 1 / 2 \text { year }\end{array}$ & 2 & $2.2 \%$ & 5 & $4.9 \%$ & 0 & $0.0 \%$ & 7 & $2.3 \%$ \\
\hline & $\mathrm{n}=91$ & & $\mathrm{n}=102$ & & $\mathrm{n}=107$ & & $\mathrm{n}=300$ & \\
\hline
\end{tabular}

Regarding "low readers" among the students, again we find that more of the students from schools with a central library only (16.7\%-) stated that they read little (one book per two months to half a year), compared to only $6.6 \%$ of the students from schools with class libraries only and $3.7 \%$ of the students from schools with combined libraries.

In terms of how much time students devote to free reading activities, a similar picture emerges (see Table 3). Much reading - more than two hours per day was done by $18 \%$ to $19 \%$ of the students. Some $70 \%$ of the students in schools with class libraries only devote a half hour to an hour per day to reading, compared to $76.7 \%$ of the students in schools with central libraries only and $81.3 \%$ of the students in schools with combined libraries. Students who read a half-hour or more per day include $99 \%$ of those from schools with combined libraries, 95\% of those from schools with a central library only, and $89 \%$ of those from schools with class libraries only.

Table 3

Average Number Of Hours Per Day Devoted By Students To Reading By Type Of Library

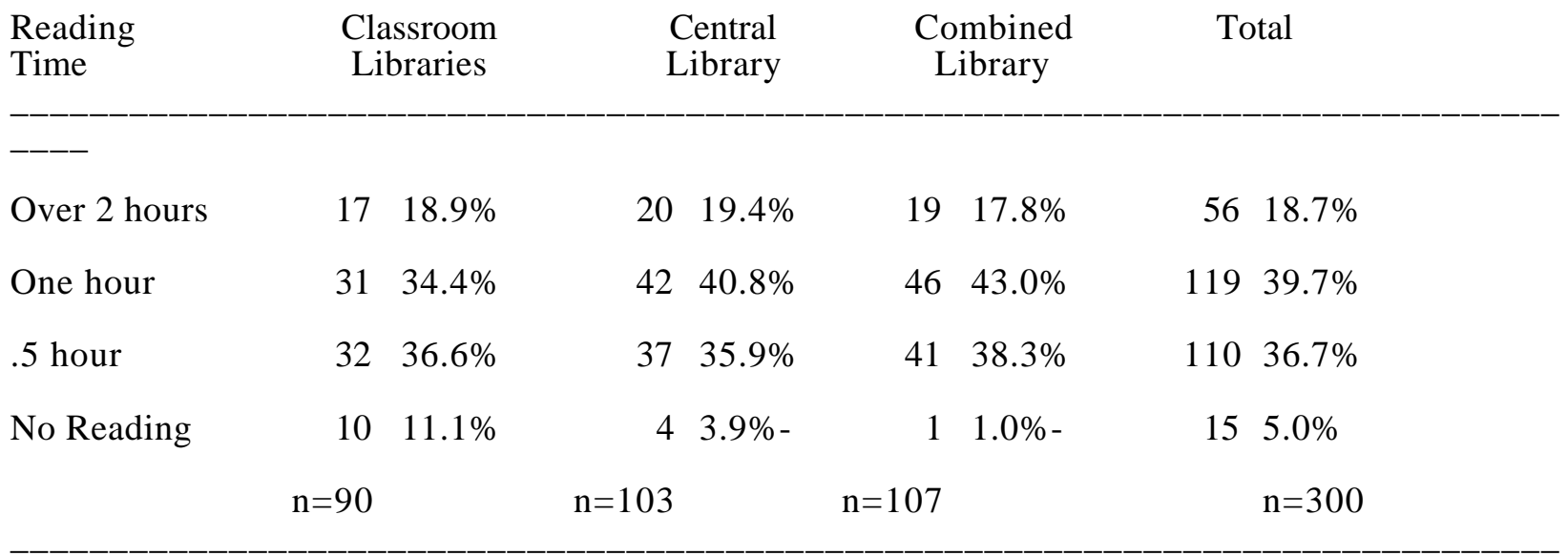


Students were asked whether there existed at present in their home a book they had borrowed from a library of any sort. Among $23.1 \%$ of those whose schools had class libraries only, no book borrowed from any library existed at the moment in their home; the figures were $14.6 \%$ for students in schools with central libraries only, and $9.3 \%$ for students in schools with combined libraries (see Table 4) . In other words, $91 \%$ of the students in schools with combined libraries had a library book in their home, compared to $85 \%$ of students in schools with a central library only and $77 \%$ of students in schools with class libraries only.

Table 4

Having A Library Book At Home

\begin{tabular}{|c|c|c|c|c|c|c|c|c|}
\hline $\begin{array}{l}\text { Having a } \\
\text { Library Book }\end{array}$ & \multicolumn{2}{|c|}{$\begin{array}{l}\text { Classroom } \\
\text { Libraries }\end{array}$} & \multicolumn{2}{|c|}{$\begin{array}{l}\text { Central } \\
\text { Library }\end{array}$} & \multicolumn{2}{|c|}{$\begin{array}{c}\text { Combined } \\
\text { Library }\end{array}$} & \multicolumn{2}{|c|}{ Total } \\
\hline No books & 21 & $23.1 \%$ & 15 & $14.6 \%$ & 10 & 9.3 & 46 & $15.3 \%$ \\
\hline $\begin{array}{l}\text { From the } \\
\text { classroom library }\end{array}$ & 29 & $31.8 \%$ & 0 & $0.0 \%$ & 0 & $0.0 \%$ & 29 & $9.6 \%$ \\
\hline $\begin{array}{l}\text { From the centra } \\
\text { library }\end{array}$ & 0 & $00.0 \%$ & 83 & $80.6 \%$ & 94 & $87.9 \%$ & 177 & $59 \%$ \\
\hline \multirow[t]{2}{*}{$\begin{array}{l}\text { From the public } \\
\text { library }\end{array}$} & 55 & $60.4 \%$ & 25 & $24.3 \%$ & 15 & $14.0 \%$ & 95 & $32.0 \%$ \\
\hline & $n=91$ & & $\mathrm{n}=103$ & & $\mathrm{n}=107$ & & $n=301$ & \\
\hline
\end{tabular}

The percentages of students who had more than one library book in their home were at least $14 \%$ of the students in schools with combined libraries, $24 \%$ of the students in schools with a central library only, and $32 \%$ of the students in schools with class libraries only. A large percentage (over $80 \%$ ) of students in schools with a central library only had a book borrowed from the central library in their home, and even more (88\%) of the students in schools with combined libraries.

In terms of books borrowed from the public library, an almost converse picture emerges. Only $14 \%$ of the students in schools with combined libraries had at the time of the study a reading book from the public library, compared to $24 \%$ of the students in schools with a central library only and $60 \%$ of the students in schools with class libraries only.

A check revealed that $24.3 \%$ of the students in schools with combined libraries were registered at the public library, compared to $39.85 \mathrm{k}$ of the students in schools with a central library only and $67 \%$ of the students in schools with class libraries only. The fact that among students in schools with class libraries only the registration in and borrowing of books from public libraries is higher than among the other two categories of students is probably connected to the fact that the former type of students lack a central library in their school. The lack of a central library in their schools, caused them to look for other source for book, outside of the school.

\section{DISCUSSION}

The disparities in reading among students in schools with the different kinds of libraries are not drastic. In reporting on amount of reading, the students in schools with combined libraries score highest, and the students in schools with class libraries only are a close second. With respect to time devoted to reading, similar percentages (18\% to 19\%) of intensive readers are found. In terms of students who devoted half an hour to an hour per day to reading, the ranking is: combined libraries, $81.3 \%$, central libraries, $76.7 \%$; class libraries, $70 \%$.

The criterion of having a library-borrowed book in the home also finds combined libraries in the highest place (91\%), followed by central libraries (85\%) and class libraries (77\%) . It should be 
remembered that class libraries are small, and their collections are limited compared to central school libraries or public libraries. However, central school libraries are more accessible to students than public libraries.

It is important to note that the class library project was held while students were in grades 2-3, but may still have exerted an influence the following year, in which the children no longer had class libraries but did have access to a central library. Thus, it may be that a certain contribution of the class library project to children's reading emerges, but the realization of this contribution depends on the existence of a central library in the school.

A class library is not a substitute for a central collection, with its variety and different levels of material, and services of a professional librarian. A class library can only constitute one approach among different approaches that can encourage children reading.

\section{REFERENCES}

Anderson, R. C., Wilson, P. T. \& Fielding, L. G. (1988). Growth in reading and how children spend their time outside of school. Reading Research Quarterly, 23, 285-303.

Bavakulty, M. (1981). Structure of school libraries. international Library Movement, 3(2/3), 60-64.

Bissett, D. (1969). The amount and effect of recreational reading in selected fifth grade classes. Unpublished doctoral dissertation, Syracuse University.

Boorstin, D. (1984). In our future A report from the Librarian of Congress to the Congress [Letter of transmittal]. Washington DC: US Congress, Joint Committee on the Library.

Chall, J. S. (1983). Stages of reading development. New York: McGraw-Hill.

Fitzgibbons, S. (1994). Factors which contribute to reading motivation by middle grade students in the United States. In A. M. Faslek (Ed.), Young people and reading: International perspectives: Papers presented at the Children's Section/Reading Research Round Table Joint Workshop, 22 August 1991, Moscow. (pp. 10-26) Hague: IFLA.

Fractor, et al. (1993). Let's not miss opportunities to promote voluntary reading: Classroom libraries in the elementary school. The Reading Teacher, 46(6), 476-484.

Francis, M. (1989). Central or classroom collection? School Libraries, 37(1),13.

Gaver, M.V. (1963). Effectiveness of centralized library service in elementary schools. New Brunswick, NJ: Rutgers University Press.

Great Britain. School Council Research Project. Children and their books. London: MacMillan.

Hepler, S. (1992). Getting started. Learning, 96, 100-103.

Hickman, J. (1981). A new perspective on response to literature: Research in an elementary school setting. Research in the Teaching of English, 15, 343-354.

Krashen, S. (1993). The power of reading: Insights from the research. Englewood, CO: Libraries Unlimited.

Memory, D. M. (1981). Voluntary reading in content-area classes. Clearing House, 54(7), 313-316.

Morrow, L. M. (1983). Home and school correlates of early interest in literature. Journal of Education Research, 76, 221-230.

Morrow, L. M. (1987). Promoting innercity children's recreational reading. The Reading Teacher, 41(3), 266-274.

Morrow, L. M. \& Weinstein, C. S. (1982) . Increasing children's use of literature through program and physical design changes. Elementary School Journal, 83(2), 131-137.

Morrow, L. M. \& Weinstein, C. S. (1986). Encouraging voluntary reading: The impact of a literature program on children's use of library centers. Reading Research Quarterly, 21(3), 330-346.

Nilsson, J. (1987). Introducing pupils to books. Scandinavian Public Library Quarterly, 20(2), 1215.

Stott, C. A. (1967) School libraries: a short manual. Cambridge University Press. 